Jurnal Ilmu-Ilmu Peternakan 25 (3): 25 - 36

ISSN: 0852-3681

E-ISSN: 2443-0765

CFakultas Peternakan UB, http://jiip.ub.ac.id/

\title{
Kualitas semen dan produksi semen beku pada bangsa sapi dan bulan penampungan yang berbeda
}

\author{
Mita Ayu Rahmawati ${ }^{1)}$, Trinil Susilawati ${ }^{2)}$ dan M. Nur Ihsan ${ }^{2)}$ \\ ${ }^{1)}$ Mahasiswa program pasca sarjana Fakultas Peternakan Universitas Brawijaya \\ 2) Fakultas Peternakan, Universitas Brawijaya, Malang \\ J1. Veteran Malang 65145 Jawa Timur \\ trinil_susilawati@yahoo.com
}

\begin{abstract}
The purpose of this research was to determine semen quality and frozen semen production of beef cattle at different month collection in Lembang Artificial Insemination Center. Beef cattle strain that used for this research are Aceh, Angus, Brahman, Limousine, Madura, Ongole and Simmental. The research parameter included semen volume, $\mathrm{pH}$, motility of spermatozoa, concentration of spermatozoa, number of spermatozoa, number of spermatozoa motil and number of frozen semen straw. The method of this research using factorial completely Randomized Design and each had 3 replication per treatment. The different of beef cattle have given a significant effect of semen volume $(\mathrm{P}<0.01)$, mortility of spermatozoa $(\mathrm{P}<0.01)$, concentration of spermatozoa $(\mathrm{P}<0.01)$, number of spermatozoa $(\mathrm{P}<0.01)$, number of spermatozoa motil $(\mathrm{P}<0.01)$ and $\mathrm{pH}(\mathrm{P}>0.05)$. Different month collection have a significant influence of semen volume $(\mathrm{P}<0.01), \mathrm{pH} \quad(\mathrm{P}<0.05)$, motility of spermatozoa $(\mathrm{P}<0.01)$, concentration of spermatozoa $(\mathrm{P}<0.01)$, number of spermatozoa $(\mathrm{P}<0.01)$, number of spermatozoa motil $(\mathrm{P}<0.01)$. Interaction between breed of beef cattle and different month of collection have given a significant influence of semen volume $(\mathrm{P}<0.01)$, motility spermatozoa $(\mathrm{P}<0.01)$, concentration spermatozoa $(\mathrm{P}<0.05)$ and number of spermatozoa motil $(\mathrm{P}<0.01)$.
\end{abstract}

Keywords: sperm motility, concentration, number of motile spermatozoa

\section{PENDAHULUAN}

Program utama Kementerian

Pertanian dalam mewujudkan ketahanan pangan hewani asal ternak berbasis sumber daya domestik adalah swasembada daging sapi. Swasembada daging akan meningkatkan kebutuhan daging di Indonesia diikuti dengan peningkatan produksi daging sapi. Berdasarkan Badan Pusat Statistika (2014) menyatakan bahwa produksi daging sapi tahun 2011 sebesar 485.335 ton, tahun 2012 sebesar 508.905 ton, tahun 2013 sebanyak 504.819 ton dan tahun 2014 sebesar 539.965 ton, namun pemenuhan daging sapi belum terpenuhi. Hal ini menyebabkan pemerintah menerapkan kebijakan impor daging dan bakalan sapi potong dari Australia. Impor daging tersebut meningkatkan devisa negara yang keluar.

Sedangkan salah satu tujuan swasembada daging adalah penghematan devisa negara. Upaya untuk mewujudkan program tersebut melalui peningkatan populasi sapi potong. Populasi sapi potong di Indonesia tersebar pada peternakan rakyat 
dan perlu pengembangan pembibitan peternakan rakyat yang dipadukan dengan industri feedlot dengan pemanfaatan teknologi Inseminasi Buatan (IB).

Balai Inseminasi Buatan (BIB) adalah instansi pemerintah yang memproduksi semen beku sapi perah dan sapi potong. BIB Lembang Jawa Barat merupakan salah satu Unit PelaksanaTeknik (UPT) Dinas Peternakan dan Kesehatan Hewan Provinsi Jawa Barat. Tugas pokok dari BIB Lembang adalah melaksanakan produksi dan pemasaran semen beku ternak unggul serta pengembangan IB. Keberhasilan IB ditentukan oleh beberapa faktor, salah satunya adalah kualitas semen yang digunakan. Salah satu faktor yang mempunyai pengaruh terhadap kualitas semen adalah bangsa dari pejantan yang ditampung. Komariah dkk. (2013) menyatakan bahwa warna, volume, $\mathrm{pH}$, konsistensi, motilitas individu, motilitas massa dan konsentrasi spermatozoa pejantan sangat bervariasi. Hal ini dipengaruhi oleh kondisi kesehatan ternak, umur ternak, kondisi lingkungan, manajemen peternakan, jenis pakan yang diberikan dan bangsa sapi yang digunakan.

Penelitian ini bertujuan untuk mengetahui perbedaan kualitas semen dan produksi semen beku pada bangsa sapi dan bulan penampungan yang berbeda, serta interaksi bangsa sapi dan bulan penampungan yang berbeda di BIB Lembang.

\section{MATERI DAN METODE}

Penelitian ini dilaksanakan di BIB Lembang, Bandung, Jawa Barat. Pengambilan data sekunder hasil penampungan mulai bulan Juli 2014-Juni 2015.

Materi yang digunakan adalah semen segar bangsa sapi potong, yaitu bangsa sapi Angus, Limousin, Simmental, Aceh,
Brahman, Madura dan Ongole. Metode yang digunakan dalam penelitian adalah percobaan faktorial dengan Rancangan Acak Lengkap (RAL) serta ulangan 3 kali. Faktor perlakuan (A) faktor bangsa sapi dibagi 7 taraf perlakuan antara lain (A1) Angus, (A2) Aceh, (A3) Brahman, (A4) Limousin, (A5) Madura, (A6) Limousin dan (A7) Simmental, sedangkan (B) Faktor bulan penampungan dibagi 12 taraf perlakuan antara lain (B1) Juli 2014, (B2) Agustus 2014, (B3) September 2014, (B4) Oktober 2014, (B5) November 2014, (B6) Desember 2014, (B7) Januari 2015, (B8) Februari 2015, (B9) Maret 2015, (B10) April 2015, (B11) Mei 2015 dan (B12) Juni 2015.

\section{Variabel pengamatan}

Variabel yang diamati dalam penelitian ini antara lain:

1. Volume semen (ml)

2. $\mathrm{pH}$ semen

3. Persentase motilitas individu (\%)

4. Konsentrasi spermatozoa (juta/ml)

5. Total Spermatozoa (juta)

6. Total Spermatozoa motil (juta)

7. Jumlah produksi semen beku (straw)

\section{Analisis data}

Data dianalisis secara ANOVA dengan Rancangan Acak Lengkap Faktorial. Apabila menunjukkan pengaruh yang nyata atau sangat nyata, akan dilakukan dengan Uji Jarak Berganda Duncan.

\section{HASIL PENGAMATAN}

\section{Volume semen}

\section{a. Pengaruh bangsa sapi terhadap volume semen}

Hasil rata-rata volume semen pada bangsa sapi potong yang berbeda ditampilkan pada Tabel 1. 
Tabel 1. Rata-rata volume semen pada bangsa sapi potong yang berbeda

\begin{tabular}{cc}
\hline Bangsa Sapi & $\bar{x} \pm \mathrm{SD}(\mathrm{ml})$ \\
\hline Aceh & $5,05 \pm 2,29^{\mathrm{a}}$ \\
Angus & $6,63 \pm 3,32^{\mathrm{b}}$ \\
Brahman & $7,00 \pm 2,65^{\mathrm{b}}$ \\
Limousin & $6,73 \pm 1,11^{\mathrm{b}}$ \\
Madura & $4,86 \pm 1,46^{\mathrm{a}}$ \\
Ongole & $6,70 \pm 1,61^{\mathrm{b}}$ \\
Simmental & $6,60 \pm 0,64^{\mathrm{b}}$ \\
\hline
\end{tabular}

Keterangan: Superskrip huruf yang berbeda pada kolom yang sama menunjukkan adanya perbedaan yang sangat nyata $(\mathrm{P}<0,01)$

Hasil analisis statistik menunjukkan adanya perbedaan yang sangat nyata $(\mathrm{P}<0,01)$, antara volume semen bangsa sapi potong yang berbeda. Hal ini sesuai dengan Akhter et al. (2013) yang menjelaskan bahwa perbedaan dalam volume semen antara pejantan disebabkan variasi bangsa.

Rata-rata volume semen tertinggi adalah bangsa Sapi Brahman dengan volume $7,00 \pm 2,65 \mathrm{ml}$, sedangkan volume terendah adalah bangsa sapi Aceh dengan volume $5,05 \pm 2,29$ ml. Brito et al. (2002) menjelaskan bahwa umur dan kelompok mempengaruhi karakteristik skrotum dan testis yang berhubungan dengan produksi spermatozoa dan kualitas semen pejantan. Ismaya (2014) juga menjelaskan bahwa umur berkorelasi dengan besar testis. Semakin besar testis, maka tubuli seminiferi akan semakin banyak dan produksi sel spermatozoa akan meningkat.

\section{b. Pengaruh bulan penampungan terhadap volume semen}

Hasil rata-rata volume semen pada bulan penampungan yang berbeda ditampilkan pada Tabel 2 berikut.

Tabel 2. Rata-rata volume semen pada bulan penampungan yang berbeda

\begin{tabular}{cc}
\hline Bulan penampungan & $\bar{x} \pm \mathrm{SD}(\mathrm{ml})$ \\
\hline Juli 2014 & $6,28 \pm 4,22^{\mathrm{ab}}$ \\
Agustus 2014 & $7,19 \pm 4,57^{\mathrm{c}}$ \\
September 2014 & $6,16 \pm 3,05^{\mathrm{ab}}$ \\
Oktober2014 & $5,88 \pm 3,36^{\mathrm{a}}$ \\
November 2014 & $5,98 \pm 3,36^{\mathrm{a}}$ \\
Desember 2014 & $5,96 \pm 2,68^{\mathrm{a}}$ \\
Januari 2015 & $5,90 \pm 2,21^{\mathrm{a}}$ \\
Februari 2015 & $6,18 \pm 2,14^{\mathrm{ab}}$ \\
Maret 2015 & $5,92 \pm 3,29^{\mathrm{a}}$ \\
April 2015 & $6,67 \pm 3,06^{\mathrm{b}}$ \\
Mei 2015 & $6,19 \pm 2,94^{\mathrm{ab}}$ \\
Juni 2015 & $6,38 \pm 2,87^{\mathrm{ab}}$ \\
\hline
\end{tabular}

Keterangan: Superskrip huruf yang berbeda pada kolom yang sama menunjukkan adanya perbedaan yang sangat nyata $(P<0,01)$

Hasil analisis statistik menunjukkan adanya perbedaan yang sangat nyata
$(\mathrm{P}<0,01)$, antara rata-rata volume semen pada bulan penampungan yang berbeda. 
David et al. (2007) menjelaskan bahwa perbedaan tahun, musim dan interaksi tahunmusim yang memberikan perbedaan yang nyata terhadap bangsa sapi. Rata-rata volume semen paling besar terdapat pada bulan Agustus 2014 yaitu 7,19 44,57 ml dan terendah pada bulan Januari 2015 yaitu

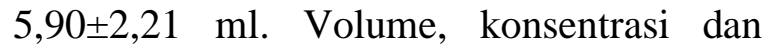
jumlah spermatozoa pertama terjadi peningkatan kemudian mengalami penurunan dengan pergantian musim. Koivisto et al. (2009) menambahkan bahwa musim dapat mempengaruhi kualitas semen lebih dari $2 \%$.

\section{c. Pengaruh interaksi bangsa sapi dan bulan penampungan yang berbeda terhadap volume semen}

Hasil analisis statistik menunjukkan adanya perbedaan yang sangat nyata $(\mathrm{P}<0,01)$, antara interaksi bangsa sapi dan bulan penampungan terhadap rata-rata volume semen. Hal ini sesuai dengan Knecht et al. (2014) bahwa adanya interaksi antara bangsa sapi dan bulan penampungan yang berbeda pada volume semen yang ditampung.

Hasil tertinggi pada bangsa sapi Angus dengan bulan penampungan pada bulan Agustus 2014 dengan rata-rata volume 9,29 ml. Bhakat et al. (2009) menjelaskan bahwa perbedaan bangsa sapi menunjukkan perbedaan beradaptasi terhadap lingkungan. Secara umum, dari semua musim, musim panas relatif memiliki hasil lebih rendah pada kualitas semen. Hal ini merupakan faktor multidimensional, seperti mengurangi konsumsi pakan, menghambat pelepasan atau respon terhadap hormon reproduksi (GnRH, FSH, LH), stress karena panas ekstrim dan menimbulkan kelelahan fisik saat ejakulasi.

\section{Persentase motilitas individu}

\section{a. Pengaruh bangsa sapi terhadap persentase motilitas individu semen}

Hasil rata-rata persentase motilitas individu semen pada bangsa sapi potong yang berbeda ditampilkan pada Tabel 3.

Tabel 3. Rata-rata motilitas individu pada bangsa sapi potong yang berbeda

\begin{tabular}{cc}
\hline Bangsa Sapi & $\bar{x} \pm \operatorname{SD}(\%)$ \\
\hline Aceh & $65,83 \pm 14,65^{\mathrm{c}}$ \\
Angus & $54,35 \pm 39,26^{\mathrm{a}}$ \\
Brahman & $64,29 \pm 18,62^{\mathrm{bc}}$ \\
Limousin & $63,81 \pm 6,18^{\mathrm{bc}}$ \\
Madura & $65,03 \pm 11,39^{\mathrm{bc}}$ \\
Ongole & $65,46 \pm 6,67^{\mathrm{bc}}$ \\
Simmental & $61,69 \pm 10,09^{\mathrm{b}}$ \\
\hline
\end{tabular}

Keterangan: Superskrip huruf yang berbeda pada kolom yang sama menunjukkan adanya perbedaan yang sangat nyata $(\mathrm{P}<0,01)$

Hasil analisis statistik menunjukkan perbedaan yang sangat nyata $(\mathrm{P}>0,01)$, antara rata-rata persentase motilitas individu semen pada bangsa sapi potong yang berbeda. Hal ini sesuai dengan penelitian Mostari et al. (2004) bahwa persentase motilitas individu spermatozoa pada bangsa sapi yang berbeda menunjukkan perbedaan yang sangat nyata.
Faktor yang mempengaruhi perbedaan persentase motilitas individu adalah keberadaan seminal plasma sebagai sumber energi. Khairi dkk. (2014) menjelaskan bahwa energi yang digunakan untuk motilitas spermatozoa berasal dari perombakan ATP melalui reaksi-reaksi penguraia menjadi ADP dan AMP. Terdapat empat bahan organik yang dapat digunakan 
oleh spermatozoa, berupa fruktosa, sorbitol, glyseril phosporil choline dan plasmalogen.

\section{b. Pengaruh bulan penampungan terhadap persentase motilitas individu semen}

Analisis statistik menunjukkan adanya perbedaan yang sangat nyata $(\mathrm{P}<0,01)$, antara rata-rata persentase motilitas individu semen pada bulan penampungan yang berbeda. Hal ini sesuai dengan penelitian Fiaz et al. (2010) menjelaskan bahwa persentase motilitas individu lebih rendah selama musim panas basah dibandingkan dengan musim lainnya.

Hasil rata-rata persentase motilitas individu semen pada bulan penampungan yang berbeda ditampilkan pada Tabel 4 .

Tabel 4. Rata-rata motilitas individu pada bulan penampungan yang berbeda

\begin{tabular}{cc}
\hline Bulan Penampungan & $\bar{x} \pm \operatorname{SD}(\%)$ \\
\hline Juli 2014 & $6,28 \pm 4,22^{\mathrm{ab}}$ \\
Agustus 2014 & $7,19 \pm 4,57^{\mathrm{c}}$ \\
September 2014 & $6,16 \pm 3,05^{\mathrm{ab}}$ \\
Oktober2014 & $5,88 \pm 3,36^{\mathrm{a}}$ \\
November 2014 & $5,98 \pm 3,36^{\mathrm{a}}$ \\
Desember 2014 & $5,96 \pm 2,68^{\mathrm{a}}$ \\
Januari 2015 & $5,90 \pm 2,21^{\mathrm{a}}$ \\
Februari 2015 & $6,18 \pm 2,14^{\mathrm{ab}}$ \\
Maret 2015 & $5,92 \pm 3,29^{\mathrm{a}}$ \\
April 2015 & $6,67 \pm 3,06^{\mathrm{b}}$ \\
Mei 2015 & $6,19 \pm 2,94^{\mathrm{ab}}$ \\
Juni 2015 & $6,38 \pm 2,87^{\mathrm{ab}}$ \\
\hline
\end{tabular}

Keterangan: Superskrip huruf yang berbeda pada kolom yang sama menunjukkan adanya perbedaan yang sangat nyata $(\mathrm{P}<0,01)$

Rata-rata persentase motilitas individu tertinggi pada bulan Februari 2015 yaitu $66,47 \pm 7,01 \%$ dan terendah pada bulan Agustus 2014 yaitu 60,64 $29,19 \%$. Penampungan pada bulan Februari berada pada musim hujan. Bhakat et al. (2014) menjelaskan bahwa persentase motilitas individu ditemukan maksimum selama musim dingin yang berbeda nyata dibandingkan dengan musim panas.

\section{c. Pengaruh interaksi bangsa sapi dan bulan penampungan terhadap persentase motilitas individu semen}

Interaksi bangsa sapi dan bulan penampungan terhadap rata-rata persentase motilitas individu semen menunjukkan perbedaan yang sangat nyata $(\mathrm{P}<0,01)$. Bangsa, umur, manajemen, nutrisi pakan dan teknik penampungan mempengaruhi persentase motilitas individu. Boujenanane et al. (2013) menyatakan bahwa musim saat penampungan berdampak terhadap kualitas semen.

Hasil tertinggi pada interaksi bangsa sapi dan bulan penampungan adalah pada bangsa sapi Madura dan bulan Mei 2015 sebesar 71,83\%. Bangsa sapi Madura merupakan sapi lokal Indonesia, sehingga tingkat adaptasi terhadap suhu lingkungan adalah tinggi. Bangsa sapi Madura dapat beradaptasi maksimal dengan kondisi panas dan bulan Mei 2015 merupakan musim panas. Hal ini sesuai dengan hasil penelitian Farooq et al. (2012) bahwa persentase motilitas individu spermatozoa lebih tinggi pada musim panas dibandingkan musim lain. 


\section{Konsentrasi spermatozoa}

\section{a. Pengaruh bangsa sapi yang berbeda terhadap konsentrasi spermatozoa}

Hasil analisis statistik menunjukkan adanya perbedaan yang sangat nyata $(\mathrm{P}<0,01)$, antara rata-rata konsentrasi spermatozoa pada bangsa sapi potong dan bulan penampungan yang berbeda. $\mathrm{Hal}$ tersebut sesuai dengan penelitian Lemma and Shemsu (2015) menunjukkan bahwa konsentrasi spermatozoa pada bangsa sapi yang berbeda menunjukkan adanya perbedaan yang sangat nyata.

Hasil rata-rata konsentrasi spermatozoa pada bangsa sapi potong yang berbeda ditampilkan pada Tabel 5 .

Tabel 5. Rata-rata konsentrasi spermatozoa pada bangsa sapi potong yang berbeda

\begin{tabular}{cc}
\hline Bangsa Sapi & $\bar{x} \pm \operatorname{SD}\left(10^{6} / \mathrm{ml}\right)$ \\
\hline Aceh & $997,153 \pm 383,65^{\mathrm{a}}$ \\
Angus & $1.047,47 \pm 527,80^{\mathrm{ab}}$ \\
Brahman & $1.153,34 \pm 577,45^{\mathrm{cd}}$ \\
Limousin & $1.132,60 \pm 177,46^{\mathrm{bcd}}$ \\
Madura & $1.084,02 \pm 392,13^{\mathrm{bc}}$ \\
Ongole & $1.079,04 \pm 373,18^{\mathrm{abc}}$ \\
Simmental & $1.184,16 \pm 191,31^{\mathrm{d}}$ \\
\hline
\end{tabular}

Keterangan: Superskrip huruf yang berbeda pada kolom yang sama menunjukkan adanya perbedaan yang sangat nyata $(\mathrm{P}<0,01)$

Bangsa sapi Simental menujukkan konsentrasi semen tertinggi dibandingkan dengan bangsa sapi yang lain. Hal ini sesuai dengan hasil pengamatan Komariah dkk. (2013) menunjukkan konsentrasi spermatozoa segar yang diperoleh dari bangsa sapi Simmental adalah $1.899,3 \times 10^{6} / \mathrm{ml}$. Hal ini dapat dipahami, mengingat sapi-sapi yang digunakan adalah milik Balai IB yang merupakan hasil seleksi yang sudah teruji kualitasnya dan dipelihara dengan manajemen yang baik.

\section{b. Pengaruh bulan penampungan terhadap konsentrasi spermatozoa \\ Hasil rata-rata konsentrasi spermatozoa pada bulan penampungan yang berbeda ditampilkan pada Tabel 6 .}

Tabel 6. Rata-rata konsentrasi spermatozoa pada bulan penampungan yang berbeda

\begin{tabular}{cc}
\hline Bulan Penampungan & $\bar{x} \pm \mathrm{SD}\left(10^{6} / \mathrm{ml}\right)$ \\
\hline Juli 2014 & $1.030,62 \pm 0,59^{\mathrm{ab}}$ \\
Agustus 2014 & $1.091,62 \pm 0,27^{\mathrm{bc}}$ \\
September 2014 & $1.101,42 \pm 0,45^{\mathrm{bc}}$ \\
Oktober2014 & $1.113,68 \pm 0,67^{\mathrm{bc}}$ \\
November 2014 & $1.089,05 \pm 0,38^{\mathrm{bc}}$ \\
Desember 2014 & $1.160,95 \pm 0,15^{\mathrm{cd}}$ \\
Januari 2015 & $1.104,68 \pm 0,29^{\mathrm{bc}}$ \\
Februari 2015 & $1.227,10 \pm 0,22^{\mathrm{d}}$ \\
Maret 2015 & $1.159,94 \pm 0,22^{\mathrm{cd}}$ \\
April 2015 & $1.094,73 \pm 0,23^{\mathrm{bc}}$ \\
Mei 2015 & $935,69 \pm 0,59^{\mathrm{a}}$ \\
Juni 2015 & $1.052,47 \pm 0,20^{\mathrm{bc}}$ \\
\hline
\end{tabular}

Keterangan: Superskrip huruf yang berbeda pada kolom yang sama menunjukkan adanya perbedaan yang sangat nyata $(\mathrm{P}<0,01)$ 
Hasil analisis statistik menunjukkan adanya perbedaan yang sangat nyata $(\mathrm{P}<0,01)$, antara rata-rata konsentrasi spermatozoa pada bulan penampungan yang berbeda. Hal ini sesuai dengan penelitian Pileckas et al. (2013) bahwa adanya perbedaan yang nyata antara konsentrasi spermatozoa pada bulan penampungan yang berbeda.

Rata-rata konsentrasi spermatozoa tertinggi pada penampungan bulan Februari 2015 yaitu $935,68 \times 10^{6} \pm 148,45 / \mathrm{ml}$, sedangkan rata-rata konsentrasi terendah pada bulan Mei 2015 sebesar $1.009,83 \times 10^{6} \pm 590,85 / \mathrm{ml}$. Perbedaan musim pada bulan Februari dan Mei mempengaruhi konsentrasi spermatozoa. Konsentrasi spermatozoa yang lebih rendah saat musim panas mungkin karena penurunan dalam konsumsi pakan dan peningkatan spermatozoa mati dan abnormal.

\section{c. Pengaruh interaksi bangsa sapi dan bulan penampungan terhadap konsentrasi spermatozoa}

Hasil analisis statistik menunjukkan adanya perbedaan yang nyata $(\mathrm{P}<0,05)$, antara interaksi bangsa sapi dan bulan penampungan terhadap rata-rata konsentrasi spermatozoa. Hal ini sesuai dengan David et al. (2007) bahwa umur dan musim berpengaruh signifikan terhadap konsentrasi spermatozoa pada bangsa yang berbeda.

Hasil tertinggi diperoleh bangsa Sapi Brahman pada bulan Oktober 2014 dengan rata-rata konsentrasi spermatozoa $1,35 \times 10^{9} / \mathrm{ml}$. Interaksi bangsa sapi dan bulan penampungan dapat dipengaruhi konsumsi pakan masing-masing sapi. Khairi dkk. (2014) menjelaskan bahwa terdapat korelasi negatif antara konsentrasi spermatozoa dengan curah hujan. Semakin tinggi curah hujan maka konsentrasi spermatozoa semakin rendah begitu juga sebaliknya.

\section{Total spermatozoa}

\section{a. Pengaruh bangsa sapi terhadap total spermatozoa}

Fuerst et al. (2004) menjelaskan bahwa petugas handling ternak memiliki pengaruh signifikan terhadap volume semen dan total spermatozoa dalam setiap ejakulasi, kolektor semen memiliki pengaruh terhadap volume semen. Hasil total spermatozoa pada bangsa sapi potong yang berbeda ditampilkan pada Tabel 7.

Tabel 7. Rata-rata total spermatozoa pada bangsa sapi potong yang berbeda

\begin{tabular}{cc}
\hline Bangsa Sapi & $\bar{x} \pm \operatorname{SD}\left(10^{6}\right)$ \\
\hline Aceh & $5.224,83 \pm 3,51^{\mathrm{a}}$ \\
Angus & $6.678,34 \pm 3,67^{\mathrm{b}}$ \\
Brahman & $7.972,90 \pm 4,01^{\mathrm{d}}$ \\
Limousin & $7.652,32 \pm 1,81^{\mathrm{cd}}$ \\
Madura & $5.201,67 \pm 1,91^{\mathrm{a}}$ \\
Ongole & $7.218,06 \pm 2,80^{\mathrm{bc}}$ \\
Simmental & $7.908,18 \pm 1,32^{\mathrm{d}}$ \\
\hline
\end{tabular}

Keterangan: Superskrip huruf yang berbeda pada kolom yang sama menunjukkan adanya perbedaan yang sangat nyata $(\mathrm{P}<0,01)$

Hasil analisis statistik menunjukkan adanya perbedaan yang sangat nyata $(\mathrm{P}<0,01)$. Hasil total spermatozoa diperoleh dengan cara mengalikan volume semen dengan konsentrasi spermatozoa.
Adhyatama dkk. (2013) juga menjelaskan bahwa jumlah spermatozoa diperoleh dengan cara mengalikan volume semen dengan konsentrasi spermatozoa. 


\section{b. Pengaruh bulan penampungan terhadap total spermatozoa \\ Hasil analisis statistik menunjukkan} adanya perbedaan yang sangat nyata $(\mathrm{P}<0,01)$, antara rata-rata total spermatozoa pada bulan penampungan yang berbeda. Hal ini sesuai dengan hasil penelitian Bhakat et al. (2014) bahwa jumlah spermatozoa yang dihasilkan memberikan hasil yang berbeda sangat nyata pada musim dingin dibandingkan musim hujan dan musim panas.

Hasil rata-rata konsentrasi spermatozoa pada bulan penampungan yang berbeda ditampilkan pada Tabel 8 .

Tabel 8. Rata-rata total spermatozoa pada bulan penampungan yang berbeda

\begin{tabular}{cc}
\hline Bulan Penampungan & $\bar{x} \pm \operatorname{SD}\left(10^{6} / \mathrm{ml}\right)$ \\
\hline Juli 2014 & $6.311,19 \pm 4,00^{\mathrm{ab}}$ \\
Agustus 2014 & $7.724,75 \pm 3,38^{\mathrm{e}}$ \\
September 2014 & $6.727 .99 \pm 5,48^{\mathrm{abc}}$ \\
Oktober2014 & $6.452,89 \pm 5,24^{\mathrm{ab}}$ \\
November 2014 & $6.791,45 \pm 5,26^{\mathrm{bcd}}$ \\
Desember 2014 & $6.933,47 \pm 3,74^{\mathrm{bcde}}$ \\
Januari 2015 & $6.560,69 \pm 3,94^{\mathrm{abc}}$ \\
Februari 2015 & $7.624,03 \pm 3,44^{\mathrm{de}}$ \\
Maret 2015 & $6.925,60 \pm 4,59^{\mathrm{bcde}}$ \\
April 2015 & $7.405,33 \pm 3,74^{\text {cde }}$ \\
Mei 2015 & $5.872,94 \pm 5,06^{\mathrm{a}}$ \\
Juni 2015 & $6.709,03 \pm 3,51^{\mathrm{abc}}$ \\
\hline
\end{tabular}

Keterangan: Superskrip huruf yang berbeda pada kolom yang sama menunjukkan adanya perbedaan yang sangat nyata $(\mathrm{P}<0,01)$

Rata-rata total spermatozoa tertinggi didapat pada bulan Agustus 2014 sebesar $7.724,75 \times 10^{6} \pm 3.383,17$ dan terendah terdapat pada bulan Mei 2015 sebesar $5.872,94 \times 10^{6} \pm 5.065,03$ juta. Kedua bulan tersebut merupakan musim kemarau sehingga suhu lingkungan meningkat menjadi panas.

\section{c. Pengaruh interaksi bangsa sapi dan bulan penampungan terhadap total spermatozoa}

Hasil analisis statistik dengan dua faktor perlakuan berbeda (bangsa sapi dan bulan penampungan) tidak memberikan perbedaan yang nyata $(\mathrm{P}>0,05)$. Hal ini sesuai dengan Ghasemi et al. (2014) yang menjelaskan bahwa musim dalam koleksi semen tidak memiliki pengaruh secara signifikan terhadap semua bangsa sapi potong.

\section{Total spermatozoa motil}

Hasil total spermatozoa motil diperoleh dengan cara mengalikan persentase motilitas individu dengan total spermatozoa. Total spermatozoa motil sangat dipengaruhi oleh motilitas dari spermatozoa pada berbagai bangsa.

Hasil total spermatozoa motil pada bangsa sapi potong yang berbeda ditampilkan pada Tabel 9. 
Tabel 9. Rata-rata total spermatozoa motil pada bangsa sapi potong yang berbeda

\begin{tabular}{cc}
\hline Bangsa Sapi & $\bar{x} \pm \operatorname{SD}\left(10^{6}\right)$ \\
\hline Aceh & $3.594,40 \pm 2,62^{\mathrm{ab}}$ \\
Angus & $3.977,40 \pm 3,15^{\mathrm{b}}$ \\
Brahman & $5.365,83 \pm 2,99^{\mathrm{d}}$ \\
Limousin & $5.030,70 \pm 0,99^{\mathrm{cd}}$ \\
Madura & $3.450,80 \pm 1,61^{\mathrm{a}}$ \\
Ongole & $4.843,26 \pm 1,81^{\mathrm{c}}$ \\
Simmental & $5.101,68 \pm 1,34^{\mathrm{cd}}$ \\
\hline
\end{tabular}

Keterangan: Superskrip huruf yang berbeda pada kolom yang sama menunjukkan adanya perbedaan yang sangat nyata $(\mathrm{P}<0,01)$

Hasil analisis statistik menunjukkan adanya perbedaan yang sangat nyata $(\mathrm{P}<0,01)$, antara total spermatozoa motil pada bangsa sapi potong yang berbeda. Hal ini sesuai dengan hasil penelitian Aerens dkk. (2012) bahwa perbedaan jumlah spermatozoa motil antar bangsa sapi berpengaruh sangat nyata terhadap jumlah spermatozoa motil semen segar.

\section{b. Pengaruh bulan penampungan terhadap total spermatozoa motil \\ Hasil total spermatozoa motil pada bulan penampungan yang berbeda ditampilkan pada Tabel 10 .}

Tabel 10. Rata-rata total spermatozoa motil pada bulan penampungan yang berbeda

\begin{tabular}{cc}
\hline Bulan Penampungan & $\bar{x} \pm \operatorname{SD}\left(10^{6} / \mathrm{ml}\right)$ \\
\hline Juli 2014 & $4.043,69 \pm 3,70^{\mathrm{ab}}$ \\
Agustus 2014 & $4.896 .03 \pm 3,29^{\mathrm{de}}$ \\
September 2014 & $4.499,18 \pm 4,00^{\mathrm{bcde}}$ \\
Oktober2014 & $4.327,70 \pm 3,63^{\mathrm{abcd}}$ \\
November 2014 & $4.198,09 \pm 4,01^{\mathrm{abc}}$ \\
Desember 2014 & $4.755,90 \pm 2,44^{\text {cde }}$ \\
Januari 2015 & $4.229,95 \pm 2,28^{\mathrm{abc}}$ \\
Februari 2015 & $5.121,42 \pm 2,15^{\mathrm{e}}$ \\
Maret 2015 & $4.648,03 \pm 2,86^{\mathrm{bcde}}$ \\
April 2015 & $4.722,37 \pm 2,49^{\text {cde }}$ \\
Mei 2015 & $3.789,83 \pm 2,78^{\mathrm{a}}$ \\
Juni 2015 & $4.534,72 \pm 2,33^{\text {bcde }}$ \\
\hline
\end{tabular}

Keterangan: Superskrip huruf yang berbeda pada kolom yang sama menunjukkan adanya perbedaan yang sangat nyata $(\mathrm{P}<0,01)$

Hasil analisis statistik menunjukkan adanya perbedaan yang sangat nyata $(\mathrm{P}<0,01)$, antara rata-rata total spermatozoa motil pada bulan penampungan yang berbeda. Hal ini sesuai dengan hasil penelitian Bhakat et al. (2014) bahwa terdapat perbedaan yang sangat nyata pada total spermatozoa motil terhadap musim dingin dan musim panas.

Rata-rata total spermatozoa tertinggi didapat pada bulan Februari 2015, sedangkan terendah didapat pada bulan Mei 2015. Setiap perubahan musim dari musim panas ke musim kemarau ataupun 
sebaliknya selalu mengalami penurunan total spermatozoa.

\section{c. Pengaruh interaksi bangsa sapi dan bulan penampungan terhadap total spermatozoa motil}

Hasil analisis statistik menunjukkan adanya perbedaan yang sangat nyata $(\mathrm{P}<0,01)$, antara interaksi bangsa sapi dan bulan penampungan terhadap rata-rata total spermatozoa motil. Hal ini sesuai dengan
Knecht, et al. (2014) bahwa adanya interaksi yang berpengaruh sangat nyata antara bangsa sapi dan bulan penampungan yang berbeda pada total spermatozoa motil.

\section{Jumlah produksi straw}

Hasil jumlah produksi straw semen beku pada bangsa sapi potong dan bulan penampungan yang berbeda ditampilkan pada Gambar 1.

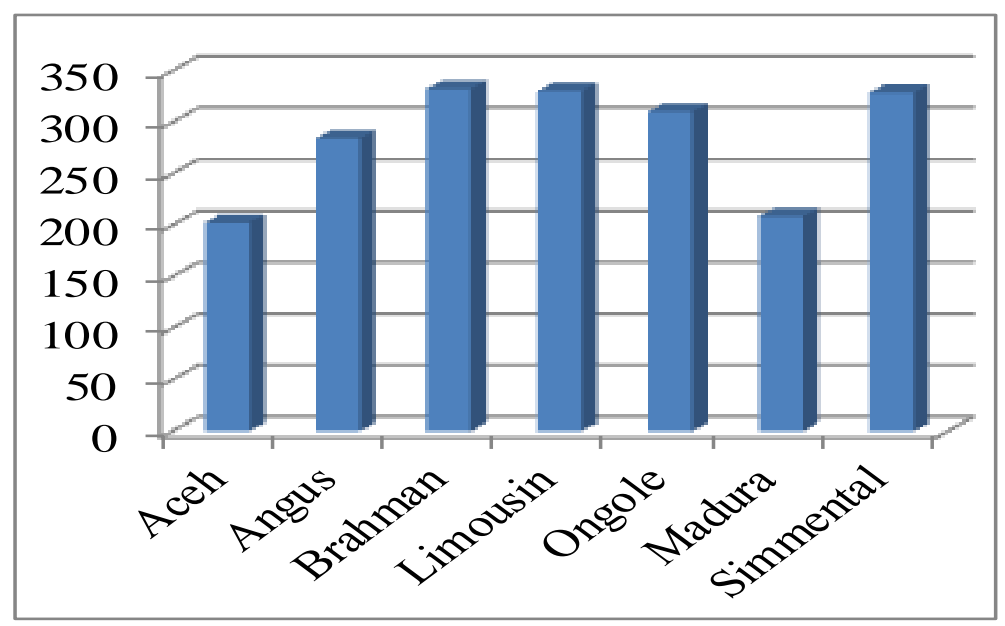

Gambar 1. Produksi straw semen beku pada bangsa sapi dan bulan penampungan yang berbeda

Berdasarkan Gambar 1. rata-rata jumlah straw pada bangsa sapi Aceh, Angus, Brahman, Limousin, Ongole, Madura dan Simmental secara berturut adalah $202,71 \pm 36,29 ; 284,53 \pm 26,23 ; 332,96 \pm 20,97$; $330,59 \pm 30,02 ; 310,41 \pm 18,95 ; 208,99 \pm 23,45$ dan 329,27 $\pm 12,09$ straw/penampungan.

Faktor yang mempengaruhi perbedaan jumlah straw semen beku yang dapat diproduksi adalah jumlah spermatozoa motil, proses pengenceran dan proses pembekuan. Bangsa sapi Brahman memiliki produksi straw semen beku tertinggi dibandingkan bangsa sapi yang lain. Hal ini dikarenakan bangsa sapi Brahman memiliki volume, persentase motilitas dan konsentrasi yang relatif tinggi, sehingga berkorelasi dengan jumlah straw semen beku yang dihasilkan.

\section{KESIMPULAN DAN SARAN}

\section{Kesimpulan}

Bangsa sapi Brahman dan bulan Februari 2015 memiliki kualitas semen lebih baik dibandingkan bangsa sapi dan bulan penampungan yang lain. Interaksi bangsa sapi dan bulan penampungan yang berbeda memberikan pengaruh terhadap kualitas semen.

\section{Saran}

Saran yang diharapkan dari penelitian antara lain :

1. Perlu penelitian lebih lanjut untuk mengkaji perbedaan kualitas semen pada masing-masing individu dalam satu bangsa.

2. Setiap pejantan perlu dievaluasi performan produksi semen beku sebagai 
dasar untuk kebijakan afkir agar usaha semen beku lebih efisien.

\section{UCAPAN TERIMA KASIH}

Terima kasih kepada pihak Balai Inseminasi Buatan Lembang Jawa Barat yang telah memberikan izin dan memberikan data penelitian.

\section{DAFTAR PUSTAKA}

Adhyatama, M., N. Isnaini dan Nuryadi. 2013. Pengaruh bobot badan terhadap kualitas dan kuantitas semen sapi simmental. J. Ternak Tropika. 14(2): 52-62.

Akhter, S., A. K. Azad, Z. Rahman dan A. Ashraf. 2013. Study on the Quality of Semen of Different Genetic Groups of Bull from Khulna Region of Bangladesh. International Journal of Pharmaceutical and Medical Research. 1(1): 19-23.

Badan Pusat Statistik. 2014. Data Pertanian. www.bps.go.id.Diakses. 2 November 2015.

Bhakat, M., T. K. Mohanty, A. K. Gupta and V. S.Raina. 2009. Effect of season and management on semen quality of breeding bulls. Agricultural Research Journal. 30(2): 79-93.

Boujenanane. I. and B. Khouloud. 2013. Environmental effects and repeatability estimates for sperm production and semen quality of holstein bulls. Department of Animal Production and Biotechnology, Institut Agronomique et Veterinaire Hassan II, Rabat, Morocco. 56 (98): $1-14$

Brito, L. F. C., A. E. D. F. Silva., L. H. Rodrigues., F. V. Vieira., L. A. G. Deragon and J. P. Kastelic. 2002. Effect of environmental factors, age and genotype on sperm production and semen quality in bos indicus and bos taurus ai bulls in Brazil. Animal Reproduction Science. 70: 181-190.
David, I., D. Xavier, L. Gilles, M. Eduardo, R.G. Christele and B. Loys. 2007. Genetic and environmental effects on semen traits in lacaune and manech tete rousse ai rams. Genet. Sel. Evol. 39(1): 405-419.

Farooq, U., I. Ahmad, A. Nazir, R. Habib and Hafsa. 2012. Seasonal variations in certain physical and biochemical attributes of semen from cholistani bulls. Pakistan Veterinary Journal. 33(4): 510-514.

Fiaz, M., H. Usmani, M. Abdullah and T. Ahmad. 2010. Evaluation of semen quality of holstein friesian and jersey bulls maintained under subtropical environment. Pakistan Veterinary Journal. 30(2): 75-78.

Fuerst, B., H. Schwarzencacher, C. Perner and J. Solkner. 2004. Environmental and age effect on the semen qualityof Austrian simmental bulls. Animal Production Journal. 4(1): 5-9.

Ismaya. 2014. Bioteknologi inseminasi buatan pada sapi dan kerbau. Gadjah Mada University Press. Yogyakarta. ISBN: 979-420-848-5.

Khairi, F., A. Muktiani dan Y. S. Ondho. 2014. Pengaruh suplementasi vitamin e, mineral selenium dan zink terhadap konsumsi nutrien, produksi dan kualitas semen sapi simmental. Agripet. 14 (1): 6-16.

Knecht. D., S. Srodon and K. Duzinski. 2014. The influence of boar breed and season on semen parameters. South African Journal of Animal Science. 44(1): 1-9.

Koivisto M. B., M. T. Costa, S. H. Perri and W.R.R. Vicente. 2009. The effect of season on semen characteristics and freezability in bos indicus and bos taurus bulls in the southeastern region of Brazil. Reproduction Domestic Animal.44(2): 587-592.

Komariah, I. Arifiantini dan F. W. Nugraha. 2013. Kaji banding kualitas 
spermatozoa sapi simmental, limousin, dan friesian holstein terhadap proses pembekuan. Buletin Peternakan. 37(3): 143-147.

Reproduction an Infertility. 6(2): 3540.

Mostari, M. P., M. G. M. Rahman, M. A. M. Y. Khandoker and S. S. Husain. 2004. Evaluation of bulls based on semen quality and herd fertility.
Lemma, A. and T. Shemsu. 2015. Effect of Age and breed on semen quality and breeding soundness evaluation of pre-service young bulls. J. Pakistan J. Biological Science. 7(12): 2177-2181.

Pileckas, V., S. Arturas and R. Violeta. 2013. Survival effect of year period on bull semen properties. Vet Med Zoot. 64(8): 76-81. 